\title{
PERHITUNGAN NILAI EFISIENSI PENCACAHAN HAMPIRAN UNTUK DETEKTOR HPGe PADA SPEKTROMETER GAMMA MENGGUNAKAN METODE KUADRAT TERKECIL
}

\section{CALCULATION OF FITTED COUNTING EFFICIENCY VALUE FOR HPGE DETECTOR ON THE GAMMA SPECTROMETER USING LEAST SQUARE METHOD}

\author{
Nazly Kurniawan ${ }^{1}$, Anto Setiawanto ${ }^{2}$, Puspitasari Ramadania ${ }^{3}$ \\ 1,2,3 Pusat Reaktor Serba Guna, Badan Tenaga Nuklir Nasional \\ email: kurniawan.nazly@batan.go.id \\ Diterima : 4 Pebruari 2020, diperbaiki : 13 Pebruari 2020, disetujui : 17 April 2020
}

\begin{abstract}
ABSTRAK
PERHITUNGAN NILAI EFISIENSI PENCACAHAN HAMPIRAN UNTUK DETEKTOR HPGe PADA SPEKTROMETER GAMMA MENGGUNAKAN METODE KUADRAT TERKECIL. Spektrometer gamma merupakan salah satu perangkat spektroskopi nuklir yang sering digunakan untuk pelaksanaan karakterisasi radiologis, yang terkait dengan aspek keselamatan radiologis pengoperasian reaktor riset. Oleh karena itu, dibutuhkan spektrometer gamma dengan performa yang baik, untuk menjamin penerapan aspek keselamatan tersebut. Salah satu indikator yang merepresentasikan performa dari suatu perangkat spektrometer gamma adalah performa analisis kuantitatif dari perangkat spektrometer gamma tersebut, yang sangat bergantung dengan efisiensi pencacahan dari detektor pada spektrometer gamma tersebut. Apabila sampel yang akan dianalisis sama dengan sumber standar yang dimiliki, maka efisiensi pencacahan dapat diperoleh dengan menggunakan metode komparatif. Namun, hampir tidak mungkin untuk menyediakan semua sumber standar yang sama dengan sampel yang akan dianalisis. Sehingga, untuk analisis kuantitatif suatu sampel yang berbeda dengan sumber standar yang tersedia, dibutuhkan nilai efisiensi pencacahan hampiran untuk rentang energi gamma tertentu. Pada tulisan ini, diberikan hasil penerapan metode kuadrat terkecil untuk perhitungan nilai hampiran dari efisiensi pencacahan detektor HPGe pada salah satu spektrometer gamma yang dikelola di Pusat Reaktor Serba Guna, untuk rentang energi dari 53,155 keV sampai dengan 1.332,502 keV. Dari percobaan yang telah dilakukan dengan menggunakan salah satu set sumber standar yang tersedia, diperoleh nilai relative error maksimum sebesar 4,01\%. Perolehan nilai relative error tersebut sudah memenuhi kriteria keberterimaan yang ditetapkan untuk nilai relative error terhitung, yaitu kurang dari $10 \%$. Dengan demikian, metode kuadrat terkecil dapat digunakan untuk menentukan nilai efisiensi pencacahan hampiran; dengan prosentase kesalahan hasil perhitungan yang rendah, apabila proses pencacahan telah dikondisikan sesuai dengan persyaratan standar.
\end{abstract}

Kata kunci : Spektrometer Gamma, Analisis Kuantitatif, dan Kurva Kalibrasi Efisiensi

\section{ABSTRACT}

CALCULATION OF FITTED COUNTING EFFICIENCY VALUE FOR HPGE DETECTOR ON THE GAMMA SPECTROMETER USING LEAST SQUARE METHOD. Gamma spectrometer is one of nuclear spectroscopy equipment which commonly operated for performing the radiological characterization, which related with radiological safety aspect of research reactor operation. Therefore, a gamma spectrometer with robust performance; is required, in order to maintain the enforcement of that safety aspect. One of the indicators which represent the gamma spectrometer performance, is the quantitative analysis performance of that gamma spectrometer, which really 
rely on the counting efficiency of the detector on a gamma spectrometer. If the prepared samples are same with the available standard sources, then the counting efficiency can be obtained by applying the comparative method. However, it is very difficult to provide all the required standard sources which have to be same with the prepared samples. Therefore, for conducting the quantitative analysis of the prepared samples; which are different with the available standard sources, then, it is required the fitted value of the counting efficiency for certain gamma energy range. This paper provides explanation about the results of least square method application, on the fitted counting efficiency value calculation for one of the gamma spectrometers with HPGe detector; which is operated in Centre For Multipurpose Reactor, with energy range from 53,155 $\mathrm{keV}$ up to $1.332,502 \mathrm{keV}$. From the experiment which has been carried out by using one of the available standard sources sets, the obtained maximum relative error was $4,01 \%$. That obtained relative error has been met the acceptable criteria for the calculated relative error, which is provisioned to be less than $10 \%$. Therefore, the least square method is reliable to be applied for calculating the fitted counting efficiency value; which error percentage of the calculation results tend to be minimum, if the counting process to be carried out in the appropriate environment, as described and required in the standard requirements.

Keywords : Gamma Spectrometer, Quantitative Analysis, and Efficiency Calibration Curve

\section{PENDAHULUAN}

Spektrometer gamma merupakan perangkat spektroskopi nuklir yang digunakan untuk menganilisis radionuklida pemancar gamma, baik secara kualitatif maupun kuantitatif. Pada instalasi reaktor riset, spektrometer gamma sering diaplikasikan untuk pelaksanaan karakterisasi radiologis yang terkait dengan aspek keselamatan radiologis pengoperasian reaktor, seperti; analisis radionuklida produk aktivasi, analisis limbah radioaktif, analisis produk fisi, dan lain - lain. Sehingga, dibutuhkan spektrometer gamma dengan performa yang baik, untuk mendukung aspek keselamatan radiologis dari pengoperasian suatu reaktor riset.

Salah satu indikator yang merepresentasikan performa dari suatu perangkat spektrometer gamma adalah performa analisis kuantitatif dari perangkat spektrometer gamma tersebut. Hasil analisis kuantitatif diperoleh melalui kalibrasi efisiensi spektrometer gamma, yang bertujuan untuk mengetahui kuantitas atau tingkat radioaktivitas dari radionuklida pemancar gamma yang terdapat pada suatu sampel. Saat ini beberapa produk perangkat spektrometer gamma telah dilengkapi dengan software yang memiliki fasilitas atau dukungan untuk menganalisis spektrum gamma dari hasil pencacahan detektor, serta dapat memberikan secara langsung atau simultan hasil analisis kualitatif ${ }^{[1]}$ dan hasil analisis kuantitatifi[2] dari suatu sampel. Namun demikian, diperlukan suatu metode untuk penentuan hasil analisis dari suatu spektrum gamma; yang dapat diaplikasikan sebagai komplemen yang bersifat korektif, bagi hasil analisis suatu software penganalisis spektrum gamma. Sehingga, dapat diketahui performa analisis yang aktual dari suatu perangkat spektrometer gamma.

Tulisan ini memaparkan hasil penerapan dari suatu metode untuk perhitungan koefisien kurva kalibrasi efisiensi, serta untuk perhitungan nilai effisiensi pencacahan hampiran dari detektor tipe semikonduktor HPGe, pada perangkat spektrometer gamma. Beberapa karya tulis memberikan paparan mengenai metode untuk penentuan atau perhitungan koefisien kurva kalibrasi efisiensi detektor HPGe $e^{[3][4][5]}$, seperti metode polynomial fitting dan least square fitting (kuadrat terkecil) dengan deskripsi 
dan penjelasan yang terbatas. Di dalam salah satu pustaka yang diacu, disebutkan; bahwa, dengan mengaplikasikan metode least square fitting diperoleh kesalahan atau bias relatif (relative error) maksimum untuk nilai hampiran dari efisiensi pencacahan adalah sebesar $3,2 \%{ }^{[3]}$. Sehingga, dapat dikatakan bahwa metode least square fitting merupakan metode yang layak terap untuk perhitungan nilai efisiensi pencacahan hampiran dari detektor HPGe pada perangkat spektrometer gamma. Pada tulisan ini dipaparkan penerapan metode least square fitting untuk menghitung koefisien kurva kalibrasi efisiensi detektor HPGe, serta hasil penerapannya untuk perhitungan nilai efisiensi pencacahan hampiran, pada salah satu spektrometer gamma yang ada di Pusat Reaktor Serba Guna (PRSG), yaitu detektor HPGe Model GC0918 Sn. 05057508.

\section{TEORI}

\section{Persamaan Kalibrasi Efisiensi}

Efisiensi pencacahan suatu detektor spektrometer gamma pada satu energi foton gamma tertentu, merupakan rasio antara jumlah cacahan atau total laju cacahan yang terdeteksi pada sebuah puncak atau spektrum gamma energi tertentu, terhadap jumlah foton gamma energi tertentu yang dipancarkan oleh suatu nuklida pemancar gamma [6]. Persamaan untuk menghitung efisiensi pencacahan tersebut adalah sebagai berikut :

$$
\varepsilon=\frac{\mathrm{R}}{\mathrm{A} \cdot \mathrm{P}_{\gamma}}
$$

dengan :

$$
\begin{aligned}
\varepsilon= & \text { Efisiensi pencahahan pada energi } \\
& \text { gamma tertentu, } \\
\mathrm{R}= & \text { Laju cacah total pada spektrum } \\
& \text { energi gamma tertentu (cacah/ } \\
& \text { detik), }
\end{aligned}
$$

$$
\begin{aligned}
\mathrm{A}= & \text { Aktivitas nuklida pemancar } \\
& \text { gamma }(\mathrm{Bq}), \\
\mathrm{P}_{\gamma}= & \text { Probabilitas pemancaran gamma } \\
& \text { untuk energi gamma tertentu. }
\end{aligned}
$$

Sedangkan, persamaan kurva kalibrasi efisiensi adalah suatu persamaan matematis yang menyatakan nilai effisiensi pencacahan sebagai fungsi energi gamma. Beberapa persamaan matematis dapat diaplikasikan sebagai persamaan kurva kalibrasi efisiensi ${ }^{[7]}$. Pada tulisan ini dipilih persamaan matematis kurva kalibrasi effisiensi yang lazim diaplikasikan pada software penganalisis spektrum gamma ${ }^{[8][9]}$, yaitu :

$$
\begin{aligned}
\ln E_{f f}= & a_{0}+a_{1} \cdot\left(\ln E_{\gamma}\right)^{1}+a_{2} \cdot\left(\ln E_{\gamma}\right)^{2} \\
& +\cdots+a_{n} \cdot\left(\ln E_{\gamma}\right)^{n}
\end{aligned}
$$

dengan :

Eff = Efisiensi pencahahan pada energi gamma tertentu,

$\mathrm{E}_{\gamma}=$ Energi gamma (keV),

$a_{0}, a_{1}, \ldots a_{n}=$ Koefisien persamaan kurva kalibrasi efisiensi.

Nilai koefisien dari persamaan (2) dapat dihitung dengan menggunakan metode Least Square Fitting. Untuk mengaplikasikan metode tersebut, dibutuhkan data nilai efisiensi pencacahan untuk beberapa energi gamma, yang dihitung menggunakan persamaan (1). Nilai cacahan dari tiap - tiap energi gamma, diperoleh dari pencacahan sumber radioaktif standar pemancar gamma multi energi seperti ${ }^{152} \mathrm{Eu}$, atau pencacahan beberapa sumber radioaktif pemancar gamma dengan rentang energi gabungan yang cukup lebar, seperti; ${ }^{133} \mathrm{Ba},{ }^{137} \mathrm{Cs}$, dan ${ }^{60} \mathrm{Co}$.

\section{Least Square Fitting}

Prinsip dari pencocokan kurva dengan metode least square atau metode kuadrat terkecil adalah dengan memini- 
malkan nilai galat (error) antara nilai hampiran suatu fungsi dengan nilai sebenarnya dari fungsi tersebut. Penerapannya pada suatu fungsi polinomial adalah apabila ada suatu fungsi polinomial sebagai berikut :

$$
\mathrm{y}_{\mathrm{i}}=\mathrm{a}_{0}+\mathrm{a}_{1} \mathrm{x}_{\mathrm{i}}+\mathrm{a}_{2} \mathrm{x}_{\mathrm{i}}^{2}+\ldots+\mathrm{a}_{\mathrm{n}} \mathrm{x}_{\mathrm{i}}^{\mathrm{n}}
$$

maka, nilai error $\left(E_{i}\right)$ dari suatu persamaan hampiran $Y_{i}$ terhadap persamaan (3) dapat dinyatakan dengan [10] :

$$
E_{i}=\sum_{i=1}^{N}\left(Y_{i}-y_{i}\right)
$$

Sedangkan nilai jumlah dari kuadrat deviasi $S$ adalah nilai kuadrat dari persamaan (4) [10] :

$\mathrm{S}=\sum_{\mathrm{i}=1}^{\mathrm{N}}\left(\mathrm{E}_{\mathrm{i}}\right)^{2}=\sum_{\mathrm{i}=1}^{\mathrm{N}}\left(\mathrm{Y}_{\mathrm{i}}-\mathrm{y}_{\mathrm{i}}\right)^{2}$

Kemudian dengan mensubstitusikan persamaan (3) ke persamaan diperoleh :

$S=\sum_{i=1}^{N}\left(Y_{i}-a_{0}-a_{1} x_{i}-a_{2} x_{i}^{2}-\cdots-a_{n} x_{i}^{n}\right)^{2}$

Nilai S menjadi minimum jika :

1. $\frac{\partial \mathrm{S}}{\partial \mathrm{a}_{0}}=\sum_{\mathrm{i}=1}^{\mathrm{N}} 2\left(\mathrm{Y}_{\mathrm{i}}-\mathrm{a}_{0}-\mathrm{a}_{1} \mathrm{x}_{\mathrm{i}}-\mathrm{a}_{2} \mathrm{x}_{\mathrm{i}}^{2}-\cdots\right.$

sehingga :

$$
\left.-a_{n} x_{i}^{n}\right)(-1)=0
$$

$\sum_{i=1}^{N} Y_{i}=a_{0} N+a_{1} \sum_{i=1}^{N} x_{i}+a_{2} \sum_{i=1}^{N} x_{i}^{2}+\cdots+a_{n} \sum_{i=1}^{N} x_{i}^{n}(7)$

$$
\left[\begin{array}{ccccc}
N & \sum_{i=1}^{N} x_{i} & \sum_{i=1}^{N} x_{i}^{2} & \cdots & \sum_{i=1}^{N} x_{i}^{n} \\
\sum_{i=1}^{N} x_{i} & \sum_{i=1}^{N} x_{i}^{2} & \sum_{i=1}^{N} x_{i}^{3} & \ldots & \sum_{i=1}^{N} x_{i}^{n+1} \\
\sum_{i=1}^{N} x_{i}^{2} & \sum_{i=1}^{N} x_{i}^{3} & \sum_{i=1}^{N} x_{i}^{4} & \ldots & \sum_{i=1}^{N} x_{i}^{n+2} \\
\vdots & \vdots & \vdots & \ddots & \vdots \\
\sum_{i=1}^{N} x_{i}^{n} & \sum_{i=1}^{N} x_{i}^{n+1} & \sum_{i=1}^{N} x_{i}^{n+2} & \cdots & \sum_{i=1}^{N} x_{i}^{2 n}
\end{array}\right]\left[\begin{array}{c}
a_{0} \\
a_{1} \\
a_{2} \\
\vdots \\
\vdots \\
\vdots \\
\vdots \\
\vdots \\
\vdots \\
a_{n}
\end{array}\right]=\left[\begin{array}{c}
\sum_{i=1}^{N} Y_{i} \\
\sum_{i=1}^{N} Y_{i} x_{i} \\
\sum_{i=1}^{N} Y_{i} x_{i}^{2} \\
\vdots \\
\sum_{i=1}^{N} Y_{i} x_{i}^{n}
\end{array}\right]
$$


Persamaan (11) dapat diselesaikan dengan menggunakan metode Eliminasi Gauss, atau; secara simultan, dapat diselesaikan dengan menerapkan prinsip operasi perkalian matriks dengan vektor.

\section{TATA KERJA}

\section{Bahan}

Pada percobaan yang dilakukan untuk memperoleh data kajian, digunakan 2 set sumber standar yang memiliki tanggal acuan yang berbeda. Sumber standar tersebut merupakan sumber standar berdimensi titik (standard point sources). Data aktivitas dari kedua set sumber standar tersebut adalah sebagai berikut :

Tabel 1. Data Tanggal Acuan dan Aktivitas Sumber Standar

\begin{tabular}{|c|c|c|c|}
\hline $\begin{array}{l}\text { Sumber } \\
\text { Standar }\end{array}$ & $\begin{array}{l}\text { Tanggal } \\
\text { Acuan }\end{array}$ & Nuklida & $\begin{array}{c}\text { Aktivitas } \\
\text { Awal } \\
(\mu \mathrm{Ci})\end{array}$ \\
\hline \multirow{3}{*}{ Set $A$} & \multirow{3}{*}{$\begin{array}{l}1 \mathrm{Mei} \\
2006\end{array}$} & ${ }^{133} \mathrm{Ba}$ & 1,120 \\
\hline & & ${ }^{60} \mathrm{Co}$ & 1,100 \\
\hline & & ${ }^{137} \mathrm{Cs}$ & 1,090 \\
\hline \multirow{3}{*}{ Set B } & \multirow{3}{*}{$\begin{array}{c}1 \text { September } \\
1989\end{array}$} & ${ }^{133} \mathrm{Ba}$ & 1,000 \\
\hline & & ${ }^{60} \mathrm{Co}$ & 1,000 \\
\hline & & ${ }^{137} \mathrm{Cs}$ & 1,000 \\
\hline
\end{tabular}

\section{Peralatan}

Sedangkan, beberapa peralatan yang digunakan antara lain :

1. Seperangkat spektrometer gamma yang dilengkapi dengan MCA dan detektor jenis HPGe produk CANBERRA (No. Seri : GC0918),

2. Perangkat lunak (software) penganalisis spektrum gamma MAESTRO-32,

3. Spacer, untuk mengatur jarak antara detektor dengan sumber standar radioatif.

\section{Metode}

Data - data untuk perhitungan nilai koefisien dari persamaan kalibrasi efisiensi diperoleh melalui tahapan sebagai berikut :

1. Menentukan efisiensi pencacahan untuk tiap - tiap energi gamma melalui percobaan,

2. Menghitung nilai koefisien dari persamaan kalibrasi kurva kalibrasi efisiensi,

3. Menghitung nilai efisiensi hampiran dan prosentase kesalahan relatifnya.

\section{Penentuan Efisiensi Pencacahan Untuk Tiap-Tiap Energi Gamma Melalui Percobaan}

Dua buah set sumber standar, yang diberi kode sumber standar Set $A$ dan sumber standar Set B; masing - masing dicacah menggunakan spektrometer gamma selama 2 jam, serta; diberi jarak $15 \mathrm{~cm}$ antara sumber standar dan detektor HP-Ge, dengan menggunakan spacer. Selain itu, sebelum dilakukan pencacahan sumber standar; perlu dilakukan kalibrasi energi terlebih dahulu pada perangkat spektrometer gamma yang digunakan, untuk menentukan kesuaian antara nomor kanal (channel number) dengan energi gamma.

Setelah diperoleh data cacahan dari masing-masing set sumber standar, maka dapat dihitung nilai efisiensi pencacahan untuk tiap energi gamma; dari masing - masing nuklida pemancar gamma, dengan mengaplikasikan persamaan (1). Data probabilitas pemancaran gamma yang baku [11], untuk perhitungan menggunakan persamaan (1), adalah sebagai berikut : 
Tabel 2. Data Probabilitas Pemancaran Gamma dari Sumber Standar Gamma

\begin{tabular}{ccc}
\hline Nuklida & $\begin{array}{c}\text { Energi Gamma } \\
(\mathrm{keV})\end{array}$ & $\begin{array}{c}\text { Probabilitas } \\
\text { Pemancaran } \\
\text { Gamma }\end{array}$ \\
\hline & 53,155 & 0,022 \\
\cline { 2 - 3 } & 80,997 & 0,34 \\
\cline { 2 - 3 } & 160,605 & 0,00646 \\
\cline { 2 - 3 }${ }^{133} \mathrm{Ba}$ & 223,25 & 0,0045 \\
\cline { 2 - 3 } & 276,39 & 0,071 \\
\cline { 2 - 3 } & 302,851 & 0,1833 \\
\cline { 2 - 3 } & 356,005 & 0,623 \\
\hline${ }^{137} \mathrm{Cs}$ & 383,851 & 0,0892 \\
\hline \multirow{2}{*}{${ }^{60} \mathrm{Co}$} & 661,66 & 0,85 \\
\cline { 2 - 3 } & $1.173,238$ & 0,999 \\
\hline & $1.332,502$ & 0,999824 \\
\hline
\end{tabular}

Perhitungan Nilai Koefisien Dari Persamaan Kalibrasi Kurva Kalibrasi Efisiensi

Dengan mengaplikasikan fungsi logaritma natural (In) untuk variabel efisiensi pencacahan dan variabel energi gamma, serta dengan menetapkan orde 4 sebagai orde maksimal untuk persamaan kurva kalibrasi efisiensi ( $n=4)$, maka bentuk persamaan (2) dapat dikonversi menjadi :

$$
\begin{aligned}
\varepsilon= & a_{0}+a_{1} \cdot(G)^{1}+a_{2} \cdot(G)^{2}+a_{3} \cdot(G)^{3} \\
& +a_{4} \cdot(G)^{4}
\end{aligned}
$$

dengan :

$\varepsilon=$ In Eff = Nilai logaritma natural dari efisiensi pencahahan pada energi gamma tertentu,

$\mathrm{G}=\ln \mathrm{E}_{\gamma}=$ Nilai logaritma natural dari energi gamma,

$a_{0}, a_{1}, a_{2}, a_{3}, a_{4}=$ Koefisien persamaan kurva kalibrasi efisiensi.

Untuk menghitung nilai koefisien persamaan kurva kalibrasi efisiensi ( $a_{0}, a_{1}$, $a_{2}, a_{3}, a_{4}$ ), dengan menggunakan prinsip persamaan (11), maka; persamaan operasi matriks yang diturunkan dari persamaan (12), dapat diformulasikan sebagai berikut :

$$
\left[\begin{array}{cccc}
\mathrm{N} & \sum_{i=1}^{\mathrm{N}} \mathrm{G}_{\mathrm{i}} & \sum_{\mathrm{i}=1}^{\mathrm{N}} \mathrm{G}_{\mathrm{i}}^{2} & \sum_{\mathrm{i}=1}^{\mathrm{N}} \mathrm{G}_{\mathrm{i}}^{3} \\
\sum_{\mathrm{i}=1}^{\mathrm{N}} \mathrm{G}_{\mathrm{i}} & \sum_{\mathrm{i}=1}^{\mathrm{N}} \mathrm{G}_{\mathrm{i}}^{2} & \sum_{\mathrm{i}=1}^{\mathrm{N}} \mathrm{G}_{\mathrm{i}}^{3} & \sum_{\mathrm{i}=1}^{\mathrm{N}} \mathrm{G}_{\mathrm{i}}^{4} \\
\sum_{\mathrm{i}=1}^{\mathrm{N}} \mathrm{G}_{\mathrm{i}}^{2} & \sum_{\mathrm{i}=1}^{\mathrm{N}} \mathrm{G}_{\mathrm{i}}^{3} & \sum_{\mathrm{i}=1}^{\mathrm{N}} \mathrm{G}_{\mathrm{i}}^{4} & \sum_{\mathrm{i}=1}^{\mathrm{N}} \mathrm{G}_{\mathrm{i}}^{5} \\
\sum_{\mathrm{i}=1}^{\mathrm{N}} \mathrm{G}_{\mathrm{i}}^{3} & \sum_{\mathrm{i}=1}^{\mathrm{N}} \mathrm{G}_{\mathrm{i}}^{4} & \sum_{\mathrm{i}=1}^{\mathrm{N}} \mathrm{G}_{\mathrm{i}}^{5} & \sum_{\mathrm{i}=1}^{\mathrm{N}} \mathrm{G}_{\mathrm{i}}^{6} \\
\sum_{\mathrm{i}=1}^{\mathrm{N}} \mathrm{G}_{\mathrm{i}}^{4} & \sum_{\mathrm{i}=1}^{\mathrm{N}} \mathrm{G}_{\mathrm{i}}^{5} & \sum_{\mathrm{i}=1}^{\mathrm{N}} \mathrm{G}_{\mathrm{i}}^{6} & \sum_{\mathrm{i}=1}^{\mathrm{N}} \mathrm{G}_{\mathrm{i}}^{7}
\end{array}\right.
$$

[Matriks A]

\section{$\left.\sum_{i=1}^{\mathrm{N}} \mathrm{G}_{\mathrm{i}}^{4}\right]$ $\sum_{i=1}^{\mathrm{N}} \mathrm{G}_{\mathrm{i}}^{5}$ $\sum_{i=1}^{N} G_{i}^{6}$ $\sum_{i=1}^{N} G_{i}^{7}$ $\sum_{i=1}^{N} G_{i}^{8}$}

[Vektor B]

$$
\left[\begin{array}{c}
\mathrm{a}_{0} \\
\mathrm{a}_{1} \\
\mathrm{a}_{2} \\
\mathrm{a}_{3} \\
\mathrm{a}_{4}
\end{array}\right]=\left[\begin{array}{c}
\sum_{\mathrm{i}=1}^{\mathrm{N}} \varepsilon_{\mathrm{i}} \\
\sum_{\mathrm{i}=1}^{\mathrm{N}} \varepsilon_{\mathrm{i}} \mathrm{G}_{\mathrm{i}} \\
\sum_{\mathrm{i}=1}^{\mathrm{N}} \varepsilon_{\mathrm{i}^{2}} \mathrm{G}_{\mathrm{i}}^{2} \\
\sum_{\mathrm{i}=1}^{\mathrm{N}} \varepsilon_{\mathrm{i}} \mathrm{G}_{\mathrm{i}}^{3} \\
\sum_{\mathrm{i}=1}^{\mathrm{N}} \varepsilon_{\mathrm{i}} \mathrm{G}_{\mathrm{i}}^{4}
\end{array}\right]
$$

[Vektor C]
Secara simultan, nilai dari Vektor B dapat dihitung dengan cara mengalikan Invers Matriks A dengan Vektor C.

Perhitungan Nilai Efisiensi Hampiran dan Prosentase Kesalahan Relatifnya

Nilai koefisien yang diperoleh dari persamaan (13), selanjutnya, disubsti tusikan ke persamaan (12) untuk menghitung nilai efisiensi hampiran.

Sedangkan, persaman untuk menghitung prosentase error dari hasil perhitungan efisiensi hampiran; dengan menggunakan persamaan kurva kalibrasi yang diperoleh, adalah sebagai berikut :

$$
\% \mathrm{RE}=\frac{|\varepsilon-\mathrm{Eff}|}{\mathrm{Eff}} \times 100 \%
$$

dengan :

$\% \mathrm{RE}=$ Prosentase relative error atau kesalahan relatif,

$\varepsilon=$ Nilai hampiran efisiensi pencacahan yang dihitung menggunakan persamaan (12),

Eff = Nilai efiesiensi pencacahan untuk tiap energi gamma yang dihitung menggunakan persamaan (1). 


\section{HASIL DAN PEMBAHASAN}

Pada percobaan yang dilakukan untuk memperoleh data dukung kajian, digunakan 2 set sumber standar pemancar gamma; berdimensi titik, yang masing - masing set terdiri dari 3 macam nuklida, yaitu : ${ }^{133} \mathrm{Ba},{ }^{137} \mathrm{Cs}$, dan ${ }^{60} \mathrm{Co}$. Dengan menggunakan ketiga buah nuklida tersebut, akan diperoleh persamaan kurva kalibrasi efisiensi untuk rentang energi gamma dari 53,155 keV sampai dengan 1.332,502 keV. Saat pencacahan sumber standar, pemberian jarak atara detektor dengan sumber standar bertujuan untuk memperkecil nilai dead time saat pencacahan sumber standar. Semakin kecil nilai dead time, maka, radiasi gamma yang tidak tercacah akan semakin sedikit. Dengan demikian, akan diperoleh efisiensi pencacahan yang lebih besar.

Penentuan kesesuaian antara nomor kanal dengan energi gamma dilakukan dengan mengacu pada hasil identifikasi software MAESTRO-32 pada tiap - tiap nomor kanal yang dipilih untuk energi 661,66 keV, 1.173,238 keV, dan
1.332,502 keV. Apabila dari hasil identifikasi MAESTRO-32 menunjukkan bahwa; pada ketiga nomor kanal yang dipilih untuk ketiga energi tersebut secara tepat menampilkan 3 puncak spektrum gamma dengan pembacaan energi masing - masing : 661,66 keV, 1.173,238 $\mathrm{keV}$, dan 1.332,502 keV, serta hasil identifikasi library MAESTRO-32 menunjukkan bahwa :

1. Energi $661,66 \mathrm{keV}$ teridentifikasi sebagai spektrum ${ }^{137} \mathrm{Cs}$,

2. Energi $1.173,238 \mathrm{keV}$ dan $1.332,502$ $\mathrm{keV}$ teridentifikasi sebagai spektrum ${ }^{60} \mathrm{Co}$,

maka, telah diperoleh kesuaian yang tepat antara nomor kanal dan energi gamma. Jika belum diperoleh kesuaian yang tepat antara nomor kanal dan energi gamma, maka perlu dilakukan kalibrasi energi ulang atau perlu dilakukan pengaturan ulang terhadap setting nomor kanal. Tampilan dari hasil pencacahan sumber standar Set A dan Set B ditunjukkan pada Gambar 1 dan Gambar 2.

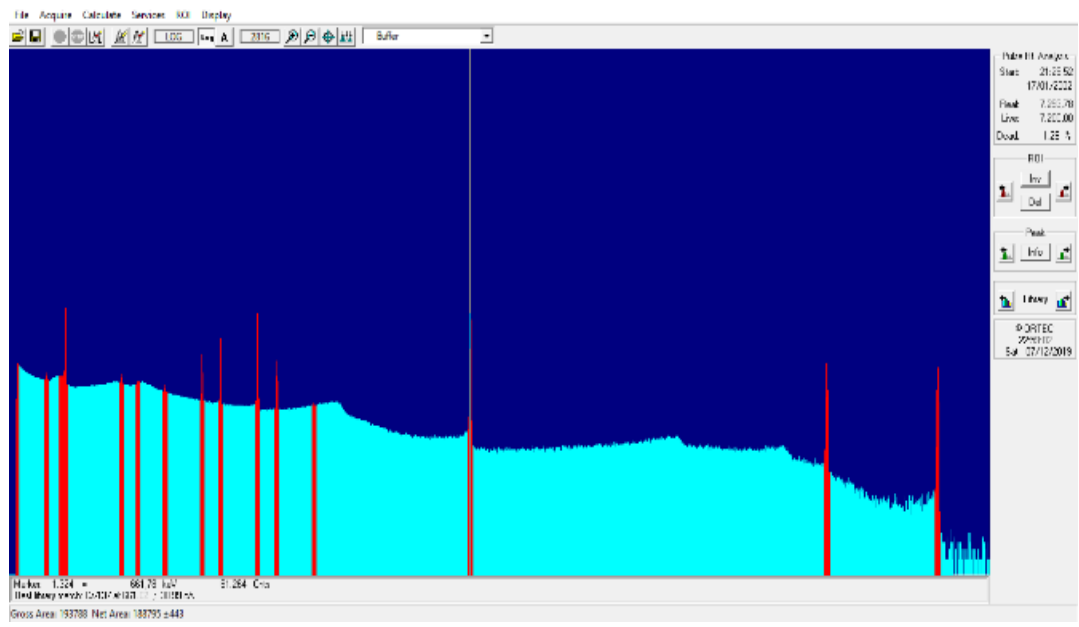

Gambar 1. Tampilan Spektrum Hasil Pencacahan Sumber Standar Set A 


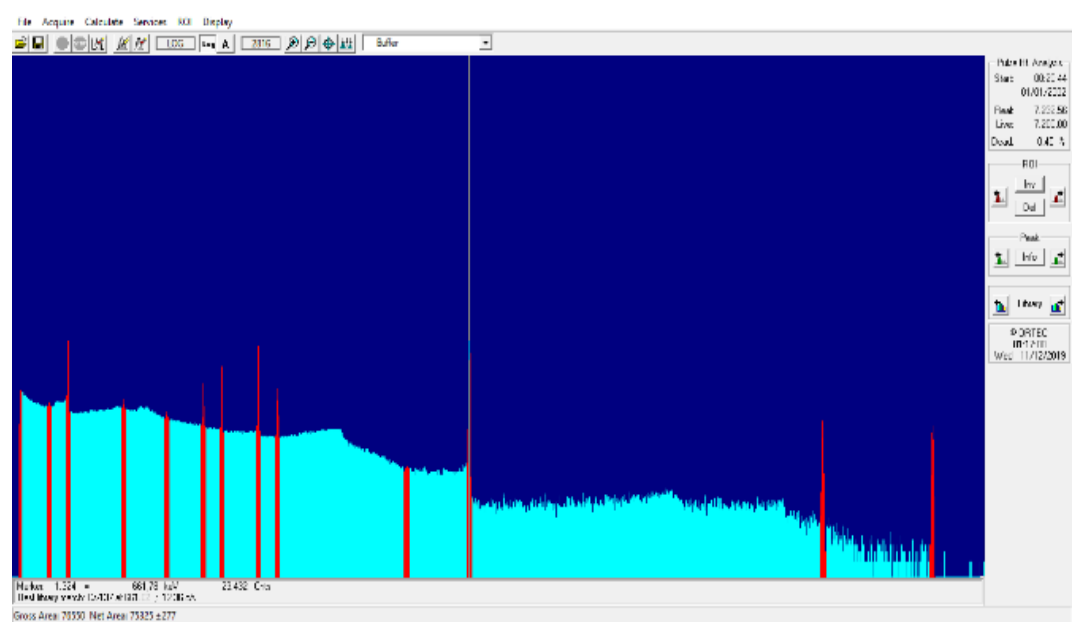

Gambar 2. Tampilan Spektrum Hasil Pencacahan Sumber Standar Set B

Nilai cacah yang diperoleh setelah pencacahan selama 2 jam, serta hasil perhitungan efisiensi pencacahan menggunakan persamaan (1) dari sumber standar set A dan set B diberikan pada tabel 3 dan tabel 4.

Tabel 3. Hasil Pencacahan dan Hasil Perhitungan Efisiensi Tiap Energi untuk Sumber Standar Set A

\begin{tabular}{ccccc}
\hline Nuklida & $\begin{array}{c}\text { Energi } \\
(\mathrm{keV})\end{array}$ & $\begin{array}{c}\text { Probabilitas } \\
\text { Pemancaran } \\
\text { Gamma }\end{array}$ & $\begin{array}{c}\text { Cacah } \\
\text { Total }\end{array}$ & $\begin{array}{c}\text { Efisiensi } \\
\text { Pencacahan Tiap } \\
\text { Energi }\end{array}$ \\
\hline & 53,155 & 0,022 & 2389 & 0,000883 \\
\cline { 2 - 5 } & 80,997 & 0,34 & 163864 & 0,003918 \\
\cline { 2 - 5 } & 160,605 & 0,00646 & 3878 & 0,004880 \\
\cline { 2 - 5 }${ }^{133} \mathrm{Ba}$ & 223,25 & 0,0045 & 1929 & 0,003485 \\
\cline { 2 - 5 } & 276,39 & 0,071 & 25247 & 0,002891 \\
\cline { 2 - 5 } & 302,851 & 0,1833 & 57345 & 0,002543 \\
\cline { 2 - 5 } & 356,005 & 0,623 & 157609 & 0,002057 \\
\hline${ }^{137} \mathrm{Cs}$ & 383,851 & 0,0892 & 20919 & 0,001906 \\
\hline \multirow{2}{*}{${ }^{60} \mathrm{Co}$} & $1.173,238$ & 0,999 & 30074 & 0,000602 \\
\cline { 2 - 5 } & $1.332,502$ & 0,999824 & 26174 & 0,000523 \\
\hline
\end{tabular}


Tabel 4. Hasil Pencacahan dan Hasil Perhitungan Efisiensi Tiap Energi untuk Sumber Standar Set B

\begin{tabular}{ccccc}
\hline Nuklida & $\begin{array}{c}\text { Energi } \\
(\mathrm{keV})\end{array}$ & $\begin{array}{c}\text { Probabilitas } \\
\text { Pemancaran } \\
\text { Gamma }\end{array}$ & $\begin{array}{c}\text { Cacah } \\
\text { Total }\end{array}$ & $\begin{array}{c}\text { Efisiensi } \\
\text { Pencacahan Tiap } \\
\text { Energi }\end{array}$ \\
\hline & 53,155 & 0,022 & 768 & 0,000954 \\
\cline { 2 - 5 } & 80,997 & 0,34 & 51366 & 0,004127 \\
\cline { 2 - 5 } & 160,605 & 0,00646 & 1329 & 0,005620 \\
\cline { 2 - 5 }${ }^{133} \mathrm{Ba}$ & 223,25 & 0,0045 & 664 & 0,004031 \\
\cline { 2 - 5 } & 276,39 & 0,071 & 8320 & 0,003201 \\
\cline { 2 - 5 } & 302,851 & 0,1833 & 19566 & 0,002916 \\
\hline$n^{137} \mathrm{Cs}$ & 356,005 & 0,623 & 53601 & 0,002350 \\
\hline \multirow{2}{*}{${ }^{60} \mathrm{Co}$} & 383,851 & 0,0892 & 7013 & 0,002148 \\
\cline { 2 - 5 } & $1.173,238$ & 0,999 & 2885 & 0,000569 \\
\hline
\end{tabular}

Dari tabel 3 dan tabel 4, dapat diketahui bahwa terdapat perbedaan atau selisih nilai dari hasil perhitungan efisiensi antara sumber standar set A dengan sumber standar set $\mathrm{B}$. Hal ini disebabkan karena sumber standar set A dan set B memiliki nilai aktivitas yang berbeda, saat dilakukan pencacahan. Dengan nilai aktivitas yang berbeda, maka; intensitas radiasi gamma yang terdeteksi oleh detektor HPGe menjadi berbeda, sehingga nilai efisiensi terhitung akan menjadi berbeda antara sumber standar set $A$ dan set $B$.

Nilai logaritma natural dari nilai energi gamma dan nilai efisiensi pencacahan, pada tabel 3 dan tabel 4, diaplikasikan untuk pencocokan kurva menggunakan metode kuadrat terkecil (least square fitting), sesuai persamaan (13). Hasil perhitungan koefisien persaamaan kurva kalibrasi efisiensi menggunakan persamaan (13), untuk sumber standar set $A$ dan set $B$, ditampilkan pada tabel 5 .

Nilai koefisien kurva kalibrasi efisiensi terhitung digunakan untuk menghitung nilai efisiensi pencacahan hampiran, sesuai dengan format persamaan (12). Gambar 3 menunjukkan kurva kalibrasi efisiensi yang memberikan informasi mengenai nilai efisiensi pencacahan dari hasil percobaan serta nilai hampirannya, sebagai fungsi energi gamma, yang diperoleh dengan menggunakan sumber standar set $A$. Untuk hasil percobaan menggunakan sumber standar set B, ditunjukkan pada gambar 4.

Tabel 5. Nilai Koefisien Kurva Kalibrasi Efisiensi Hasil Perhitungan Menggunakan Metode Least Square Fitting

\begin{tabular}{ccc}
\hline \multirow{2}{*}{$\begin{array}{c}\text { Koefisien } \\
\text { Kurva } \\
\text { Kalibrasi } \\
\text { Efisiensi }\end{array}$} & \multicolumn{2}{c}{ Nilai Koefisien } \\
\cline { 2 - 3 } & $\begin{array}{c}\text { Sumber } \\
\text { Standar Set A }\end{array}$ & $\begin{array}{c}\text { Sumber } \\
\text { Standar Set B }\end{array}$ \\
\hline $\mathrm{a}_{0}$ & $-243,2852$ & $-109,6136$ \\
\hline $\mathrm{a}_{1}$ & 159,8208 & 56,5048 \\
\hline $\mathrm{a}_{2}$ & $-39,6242$ & $-10,1337$ \\
\hline $\mathrm{a}_{3}$ & 4,3098 & 0,6297 \\
\hline $\mathrm{a}_{4}$ & $-0,1747$ & $-0,0054$ \\
\hline
\end{tabular}




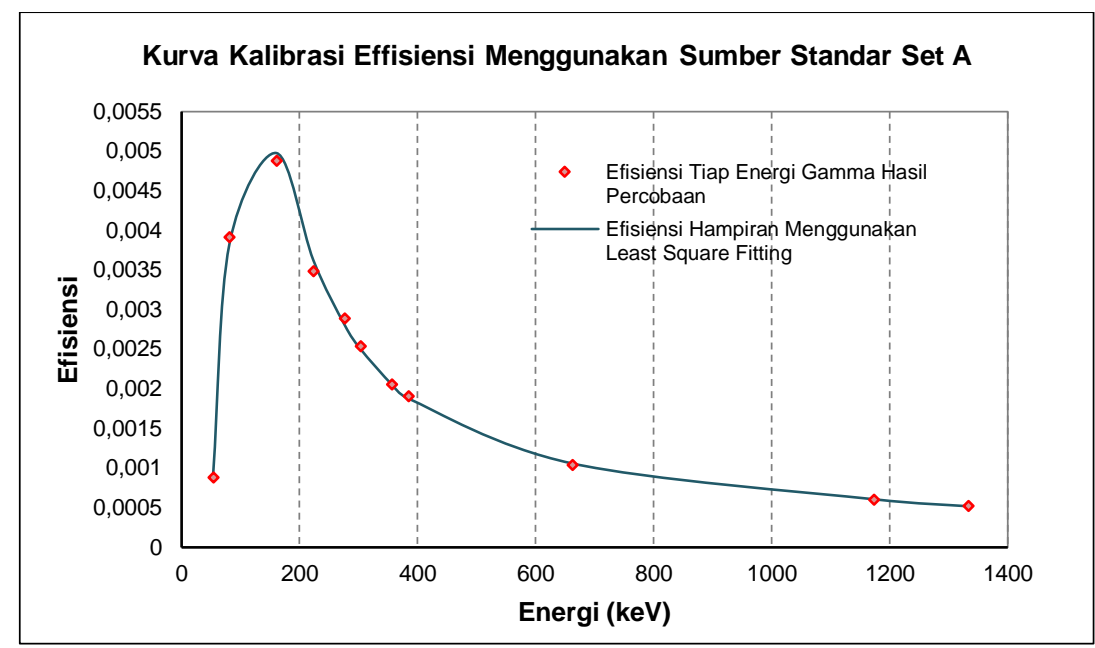

Gambar 3. Kurva Kalibrasi Efisiensi Menggunakan Sumber Standar Set A

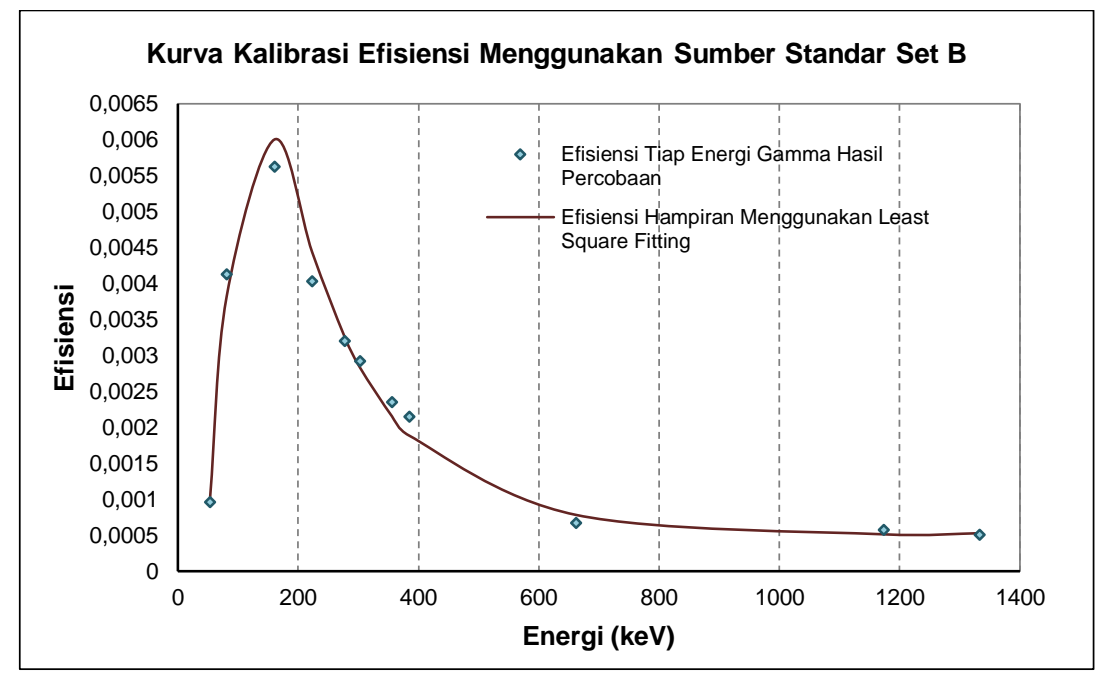

Gambar 4. Kurva Kalibrasi Efisiensi Menggunakan Sumber Standar Set B

Seperti yang ditunjukkan pada kurva kalibrasi efisiensi di gambar 3 dan gambar 4 , nilai efisiensi meningkat pada rentang energi dari 53,155 keV sampai dengan kisaran energi $155 \mathrm{keV}$. Hal ini dikarenakan terjadinya proses absorpsi foton gamma energi rendah oleh bagian cap atau tutup detektor. Sedangkan, foton gamma dengan energi yang lebih tinggi memiliki cukup energi untuk menembus cap detektor; sehingga proses absorpsi untuk foton gamma dengan energi yang lebih tinggi akan semakin berkurang, dan efisiensi tercacahnya foton gamma akan meningkat. Namun, terjadi penurunan efisiensi untuk pecacahan foton gamma 
dengan energi di atas $155 \mathrm{keV}$. Hal ini dikarenakan ketika terjadi kenaikan energi dari $155 \mathrm{keV}$ hingga lebih dari $1 \mathrm{MeV}$, sebagian besar foton gamma masih berinteraksi dengan material detektor. Tetapi, interaksi yang berupa hamburan compton lebih banyak terjadi dibandingkan dengan interaksi tercacahnya foton gamma. Sehingga, efisiensi pencacahan menjadi berkurang untuk energi foton gamma di atas $155 \mathrm{keV}$.

Pada kurva di gambar 3, nilai efisiensi hampiran hampir semuanya sangat bersesuaian dengan atau sangat mendekati nilai efisiensi hasil percobaan menggunakan sumber standar set $A$. Sedangkan, pada kurva di gambar 4; nilai efisiensi hampiran pada beberapa titik energi, kurang mendekati nilai efisiensi hasil percobaan menggunakan sumber standar set B. Besar kecilnya prosentase selisih antara nilai efisiensi hampiran dengan nilai efisiensi hasil percobaan, yang dihitung menggunakan persamaan (14), diberikan pada tabel 6.

Tabel 6. Perbandingan Nilai Relative Error Antara Efisiensi Hampiran Sumber Standar Set A dan Efisiensi Hampiran Sumber Standar Set B

\begin{tabular}{|c|c|c|c|c|c|c|c|}
\hline \multirow[b]{2}{*}{ Nuklida } & \multirow[b]{2}{*}{$\mathrm{E}(\mathrm{keV})$} & \multicolumn{3}{|c|}{ Sumber Standar Set A } & \multicolumn{3}{|c|}{ Sumber Standar Set B } \\
\hline & & $\begin{array}{c}\text { Efisiensi } \\
\text { Hasil } \\
\text { Percobaan }\end{array}$ & $\begin{array}{c}\text { Efisiensi } \\
\text { Hampiran }\end{array}$ & $\begin{array}{c}\text { Relative } \\
\text { Error } \\
(\%)\end{array}$ & $\begin{array}{c}\text { Efisiensi } \\
\text { Hasil } \\
\text { Percobaan }\end{array}$ & $\begin{array}{c}\text { Efisiensi } \\
\text { Hampiran }\end{array}$ & $\begin{array}{c}\text { Relative } \\
\text { Error } \\
(\%)\end{array}$ \\
\hline \multirow{8}{*}{${ }^{133} \mathrm{Ba}$} & 53,155 & 0,00088 & 0,00089 & 0,85 & 0,00095 & 0,00098 & 2,88 \\
\hline & 80,997 & 0,00392 & 0,00383 & 2,28 & 0,00413 & 0,00382 & 7,55 \\
\hline & 160,605 & 0,00488 & 0,00498 & 1,99 & 0,00562 & 0,00600 & 6,83 \\
\hline & 223,25 & 0,00348 & 0,00362 & 4,01 & 0,00403 & 0,00444 & 10,07 \\
\hline & 276,39 & 0,00289 & 0,00281 & 2,93 & 0,00320 & 0,00328 & 2,37 \\
\hline & 302,851 & 0,00254 & 0,00251 & 1,45 & 0,00292 & 0,00283 & 2,92 \\
\hline & 356,005 & 0,00206 & 0,00206 & 0,00 & 0,00235 & 0,00215 & 8,39 \\
\hline & 383,851 & 0,00191 & 0,00188 & 1,38 & 0,00215 & 0,00189 & 12,05 \\
\hline${ }^{137} \mathrm{Cs}$ & 661,66 & 0,00104 & 0,00106 & 1,51 & 0,00067 & 0,00078 & 17,45 \\
\hline \multirow{2}{*}{${ }^{60} \mathrm{Co}$} & $1.173,238$ & 0,00060 & 0,00061 & 0,81 & 0,00057 & 0,00051 & 9,80 \\
\hline & $1.332,502$ & 0,00052 & 0,00052 & 0,90 & 0,00050 & 0,00053 & 5,38 \\
\hline
\end{tabular}

Relative error maksimum dari nilai efisiensi hampiran untuk nilai efisiensi yang diperoleh melalui percobaan menggunakan sumber standar set $A$ adalah sebesar $4,01 \%$. Nilai tersebut adalah relative error dari efisiensi hampiran pada energi gamma 223,25 $\mathrm{keV}$, yang merupakan salah satu energi gamma dari nuklida ${ }^{133} \mathrm{Ba}$. Mengacu pada gambar 3, energi gamma 223,25 keV berada di bagian slope (landai) pada area knee (lengkungan), dari kurva kalibrasi efisiensi. Nilai efisiensi hampiran pada area knee dari kurva kalibrasi efisiensi berpotensi memiliki error yang cukup besar, apabila distribusi data efisiensi fungsi energi gamma pada area knee; yang diaplikasikan untuk perhitungan nilai hampiran, kurang merata, atau jumlah data pada area knee tersebut terlalu sedikit. Selain itu, energi gamma 223,25 $\mathrm{keV}$ memiliki probablitas gamma yang relatif kecil, yaitu sebesar 0,0045 (0,45\%). Sedangkan, relative error maksimum 
dari nilai efisiensi hampiran untuk nilai efisiensi yang diperoleh melalui percobaan menggunakan sumber standar set B mencapai $17,45 \%$. Hampir semua nilai efisiensi hampiran yang diperoleh dari perhitungan dan percobaan menggunakan sumber standar set $B$, memiliki nilai relative error yang lebih besar, dibandingkan dengan nilai relative error dari nilai efisiensi hampiran yang diperoleh dari perhitungan dan percobaan menggunakan sumber standar set $A$. Sesuai tabel 1 , sumber standar set B memiliki waktu acuan yang lebih outdated dari sumber standar set $A$, dan kedua set sumber standar tersebut memiliki nilai aktivitas awal yang hampir sama. Dengan demikian, pada tahun 2019; nuklida nuklida dari sumber standar set B memiliki aktivitas yang lebih rendah dibandingkan dengan nuklida - nuklida dari sumber standar set A. Nuklida dengan aktivitas yang lebih rendah memerlukan waktu pencacahan yang lebih lama, agar diperoleh spektrum cacahan yang lebih aktual, dan memenuhi persyaratan distribusi gaussian.

\section{KESIMPULAN}

Kesimpulan yang dapat diambil dari percobaan dan kajian yang telah dilakukan adalah sebagai berikut :

1. Perhitungan nilai efisiensi hampiran dengan metode kuadrat terkecil (least square fitting) telah memberikan nilai efisiensi hampiran yang mendekati nilai efisiensi pencacahan hasil percobaan dengan menggunakan sumber standar set A. Hal ini didasarkan pada nilai relative error maksimum yang sebesar $4,01 \%$, sesuai yang tercantum pada tabel 6 . Nilai relative error tersebut adalah nilai relative error untuk efisiensi hampiran energi gamma 223,25 keV, dengan nilai efisiensi hampiran sebesar 0,00362 dan nilai efisiensi hasil percobaan sebesar 0,00348.

Perolehan tingkat kesuaian antara hasil percobaan dan hasil perhitungan tersebut, didukung oleh pengkodisian percobaan dengan menggunakan sumber standar set $A$; yang telah cukup memenuhi persyaratan dari beberapa aspek, yaitu : jarak antara detektor dengan sumber standar, lama pencacahan, dan nilai aktivitas dari sumber standar set $A$,

2. Sedangkan, dari tabel 6 dapat diketahui bahwa pada percobaan menggunakan sumber standar set $B$; diperoleh nilai relative error maksimum dari nilai efisiensi hampiran terhitung yang cukup tinggi, yaitu mencapai $17,45 \%$. Nilai relative error tersebut adalah nilai relative error untuk efisiensi hampiran energi gamma $661,66 \mathrm{keV}$, dengan nilai efisiensi hampiran sebesar 0,00078 dan nilai efisiensi hasil percobaan sebesar 0,00067 . Hal ini dapat disebabkan karena aspek durasi pencacahan sumber standar set B yang kurang tepat atau tidak cukup lama, jika mengacu pada nilai aktivitas sumber standar set B yang lebih rendah daripada nilai aktivitas sumber standar set $A$, serta waktu acuan standar set $B$ yang lebih outdated dari sumber standar set $A$.

\section{SARAN}

Beberapa hal yang harus diperhatikan dan dipertimbangkan untuk meningkatkan hasil dari percobaan dan kajian yang telah dilakukan, atau dapat digunakan sebegai ide landasan untuk percobaan dan kajian yang selanjutnya, antara lain :

1. Perolehan hasil pencocokkan (fitting) dengan menggunakan metode kuadrat terkecil (least square) perlu dibandingkan dengan hasil fitting menggunakan metode lain, 
2. Perlu ditetapkan batas maksimum yang dapat diterima, untuk perolehan nilai relative error,

3. Metode kuadrat terkecil (least square) untuk perhitungan nilai efisiensi hampiran, perlu diterapkan pada percobaan lain yang menggunakan sumber standar dengan jenis dan dimensi yang berbeda.

\section{DAFTAR PUSTAKA}

[1] ORTEC ${ }^{\circledR} . \quad$ MAESTRO ${ }^{\circledR}$-32, MCA Emulator for Microsof ${ }^{\circledR}$ Windows $^{\circledR}$ $98^{\circledR}, 2000^{\circledR}, N T^{\circledR}$, and $X P^{\circledR}$ : Software User's Manual, 2002.

[2] ORTEC ${ }^{\circledR}$. GammaVision ${ }^{\circledR}-32$, Gamma-Ray Spectrum Analysis and MCA Emulator for Microsoft ${ }^{\circledR}$ Windows $^{\circledR} 98^{\circledR}, 2000^{\circledR}, N T^{\circledR}$, and $X P^{\circledR}$ : Software User's Manual, 2003.

[3] Geraldo, L.P., Smith, D.L. Covariance Analysis and Fitting of Germanium Gamma-Ray Detector Efficiency Calibration Data. Nuclear Instruments and Methods in Physics Research, A290:499 - 508, 1990.

[4] Venturini, L., Vanin, V.R. HPGe Detector Eficiency Calibration for Extended Sources in the 50 - 1400 keV Energy Range. Applied Radiation and Isotopes, 44(No. 7):999 - 1002, 1993.

[5] Alnour, I.A., et al. New Approach For Calibration The Efficiency Of HpGe Detectors. Advancing Nuclear Research and Energy Development, 1584:38 - 44, 2014.

[6] Gilmore, Gordon R. Practical Gamma-ray Spectrometry. John Wiley \& Sons, Ltd, $2^{\text {nd }}$ edition, 2008.
[7] Seymour, R.S., Andreaco, M.S., Pierce, J. Evaluation of Energy Efficiency Fitting Functions for HPGe Detectors. Journal of Radioanalytical and Nuclear Chemistry, 123(No. 2):529 - 550, 1988.

[8] Canberra Industries, Inc. Genie ${ }^{\mathrm{TM}}$ 2000, Spectroscopy Software : Operations Manual, 2006.

[9] Baltic Scientific Instruments, Ltd. SpectraLineGP, Precision Processing of Gamma-spectra : User's Manual, 2014.

[10] Chapra, Steven C., Canale, Raymond P. Numerical Methods for Engineers. McGraw Hill, $5^{\text {th }}$ edition, 2006.

[11] Schotzig, U., Schrader, $H$. Halbwertszeiten und PhotonenEmissionswahrscheinlichkeiten von haufig verwendeten Radionukliden. Physikalisch-Technische Bundesanstalt, $1^{\text {st }}$ edition, 1984.

[12] Knoll, Glenn F. Radiation Detection and Measurement. John Wiley \& Sons, Ltd, $4^{\text {th }}$ edition, 2010.

[13] Moens, L., Hoste, J. Calculation of The Peak Efficiency of High-Purity Germanium Detectors. Applied Radiation and Isotopes, 34(No. 8):1085 - 1095, 1983.

[14] Helmer, R.G. Efficiency Calibration of a Ge Detector For $30-2800 \mathrm{keV} \gamma$ Rays. Nuclear Instruments and Methods, 199:521 - 529, 1982.

[15] Ishizu, H., Yamada, T. Absolute Peak-Efficiency Calibration of A WellType Germanium Detector Using Multiple Gamma-Emitting Nuclides with The "Solver" Add-In in Excel ${ }^{\mathrm{TM}}$. Applied Radiation and Isotopes, 126: 158 - 161, 2017. 